\title{
PROGNOSTIC FACTORS FOR VULVAR CANCER
}

\author{
Ivana Miljanović-Špika ${ }^{1,2}$, Maja Drežnjak Madunić ${ }^{2}$,Zlatko Topolovec ${ }^{1,2}$, \\ Dajana Kujadin Kenjereš ${ }^{4}$ and Domagoj Vidosavljevićc ${ }^{1,3}$ \\ ${ }^{1}$ Department of Obstetrics and Gynecology, Faculty of Medicine, \\ Josip Juraj Strossmayer University of Osijek, Osijek, Croatia; \\ ${ }^{2}$ Osijek University Hospital Center, Osijek, Croatia; \\ ${ }^{3}$ Department of Obstetrics and Gynecology, Vukovar General Hospital, Vukovar, Croatia; \\ ${ }^{4}$ Department of Internal Medicine, Vukovar General Hospital, Vukovar, Croatia
}

\begin{abstract}
SUMMARY - The aim of this retrospective study was to show the effect of clinical, pathologic, cytologic and therapeutic prognostic factors on treatment outcome and survival of patients suffering from vulvar cancer and to determine prognostic significance of each of the individual factors, their mutual significance and impact on survival. The study included patients treated for vulvar cancer at Department of Gynecology and Obstetrics, Osijek University Hospital Centre during the 2000-2011 period. Retrospective analysis included data from patient medical files, along with their pathologic and cytologic findings, and oncologist findings. The study included 59 patients aged 45 to 88 years. Diagnosis was based on pathologic and cytologic status and staging. Univariate analysis showed the lymph node status, adjuvant radiotherapy, chemotherapy and clinical staging of the disease to be statistically significant prognostic factors for overall survival and prognosis of vulvar cancer patients. Multivariate analysis of independent prognostic factors for survival of vulvar cancer patients yielded lymph node status, adjuvant radiotherapy and chemotherapy as positive prognostic factors.
\end{abstract}

Key words: Vulva; Cancer; Survival; Chemotherapy; Staging

\section{Introduction}

Vulvar cancer is a rare malignant disease of the female sexual system. If diagnosed at an early stage, it is curable. Survival is largely due to the absence of lymphatic metastases. This is primarily a disease of older age groups, but it is ever more common in younger ages, especially in the form of human papillomavirus (HPV) related infection, which is the source of vulvar intraepithelial neoplasia ${ }^{1}$. Treatment of the initial stage of the disease is primarily surgical, whereas radiotherapy and chemoradiotherapy are used in the treatment of advanced stage of the disease ${ }^{2}$. According to recent data, survival significantly depends on the number of

Correspondence to: Assist. Prof. Domagoj Vidosavljevic, PhD, Department of Obstetrics and Gynecology, Vukovar General Hospital, Bolnička 5, HR-32000 Vukovar, Croatia

E-mail: domagoj.vidosavljevic@gmail.com

Received July 2, 2018, accepted September 24, 2018 affected lymph nodes, size of primary lesion, depth of invasion, and involvement of the lymphopapular space $^{3}$.

Vulvar cancer is a relatively rare type of cancer that accounts for $1 \%$ of all cancers in women and $4 \%$ of all gynecologic cancers. In the United States, there are 1-2 vulvar cancer patients per 100,000 women. In about two-thirds of women, it occurs between 60 and 80 years of life. Some studies show that half of the patients are aged over 70 years. Recently, the incidence of the disease has increased. The incidence is higher in developed than in underdeveloped countries. However, about $15 \%$ of patients with congestive heart disease suffer from this disease before the age of 40 . In younger age, the occurrence of cancer with HPV infection in its genesis is more common and develops from a premalignant lesion (vulvar intraepithelial neoplasia). It is believed that about $80 \%$ of untreated premalignant lesions progress to invasive disease $\mathrm{H}^{4}$. 


\section{Patients and Methods}

The study included patients treated for vulvar cancer at Department of Gynecology and Obstetrics, Osijek University Hospital Centre during the 20002011 period. Retrospective analysis included data collected from disease history, operative protocols, histopathologic and cytologic findings, and oncologist findings. The study included 59 patients aged 45 to 88 years. The following prognostic factors were analyzed:

\section{Clinical factors}

- clinical stage (divided into four groups); and

- age (recorded and graphically depicted throughout the five-year period)

\section{Pathologic and cytologic factors}

- histologic type of tumor;

- histologic grade (divided into three stages);

- tumor distance from surgical edge of the preparation (shown in millimeters and divided into groups of 0-5 mm, 6-10 mm, 11-15 mm, 16-20 $\mathrm{mm}$ and $>20 \mathrm{~mm}$ );

- depth of invasion (shown in millimeters and divided into groups of $<5 \mathrm{~mm}, 1-5 \mathrm{~mm}$ and $>5 \mathrm{~mm}$ );

- tumor size (shown in centimeters and divided into groups of 0-1 cm, $1.1-2 \mathrm{~cm}, 2.1-3 \mathrm{~cm}, 3.1-4$ $\mathrm{cm}, 4.1-5 \mathrm{~cm}$ and $>5 \mathrm{~cm}$ ); and

- lymph node status (shown by the number of removed lymph nodes and number of lymph nodes affected by the tumor)

\section{Therapy factors}

- surgical treatment; and

- adjuvant chemotherapy (performed/not performed)

\section{Statistical methods}

Statistical analysis was performed using SPSS statistical software (Statistics for Windows 17.0, SPSS Inc., Chicago, USA). The level of statistical significance was set at $\mathrm{p}<0.05$. Measured variables were shown graphically and in tables. The normality of distribution of the variables was tested by Kolmogorov Smirnov test. Categorical variables were expressed as number (frequency) and percentage (\%), and continuous vari- ables as median and interquartile range, or as arithmetic mean with standard deviation. To show the effect of particular factors on mortality, Kaplan-Meier curves and binary logistic regression analysis (Cox regression test) were used. Also, the $\chi^{2}$-test was used to assess differences among particular factors and mortality.

\section{Results}

The survey involved 59 subjects. Of the total number of patients, 16 patients died and overall survival rate was $72.9 \%$. Figure 1 shows Kaplan-Meier overall survival curve. Recurrence occurred in 17 (28.8\%) patients within a mean of 5.6 months. Disease recurrence within 6 months was recorded in two (11.8\%) patients and within 12 months in eight (47.1\%) patients (Table 1).

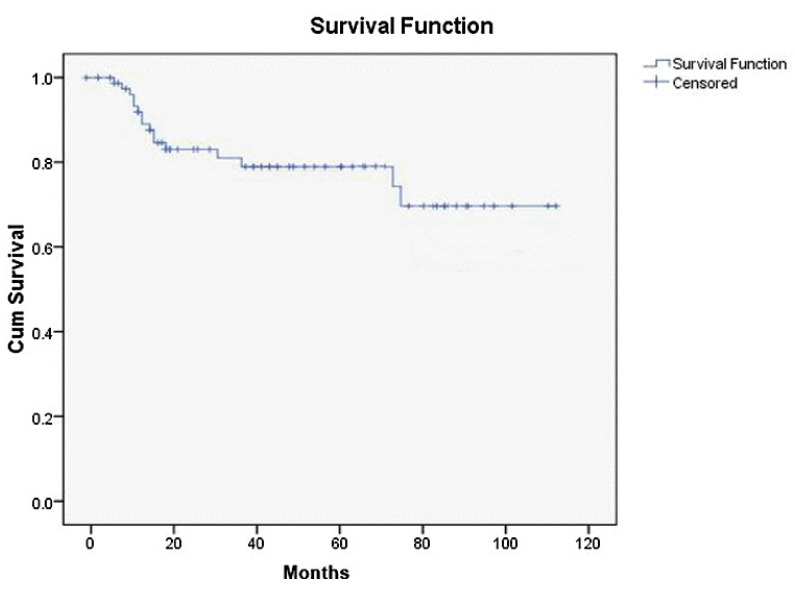

Fig. 1. Kaplan-Meier overall survival curve.

Table 1. Follow-up according to outcome

\begin{tabular}{|l|l|l|l|}
\hline & Mean (SD) & Minimum & Maximum \\
\hline $\begin{array}{l}\text { Months to } \\
\text { recurrence } \\
\text { Months of } \\
\text { follow-up to } \\
\text { recurrence } \\
\begin{array}{l}\text { Months of } \\
\text { follow-up to } \\
\text { death }\end{array}\end{array}$ & 6.59 (14.005) & 0 & 70 \\
\hline
\end{tabular}

Most cases (37\%) were diagnosed with the Féderation Internationale de Gynécologie et d'Obstétrique (FIGO) stage II, followed by FIGO stage I (32\%), FIGO stage III (27\%) and FIGO stage IV (4\%). Fig- 


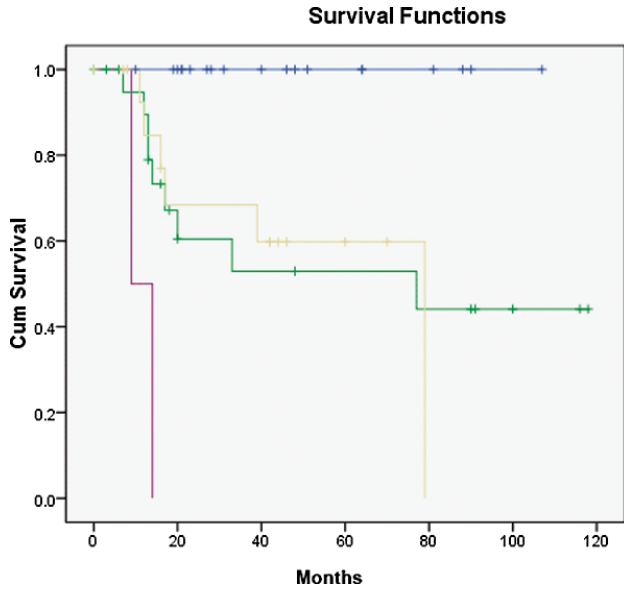

Fig. 2. Kaplan-Meier curve of patient survival according to FIGO staging.

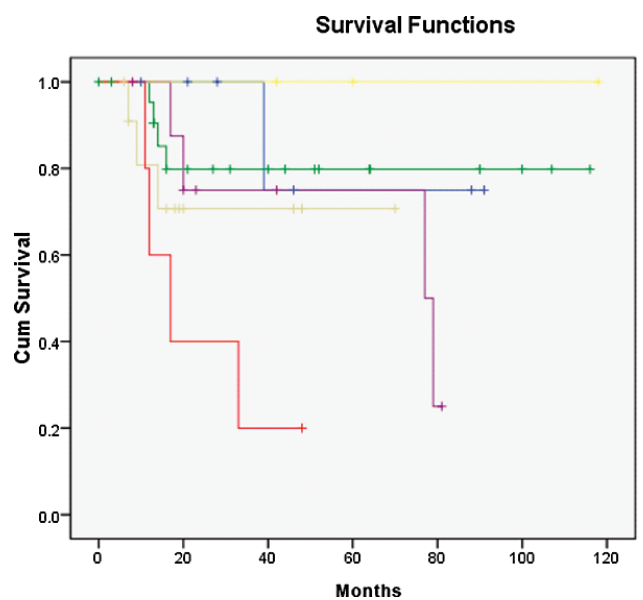

Fig. 3. Kaplan-Meier survival curve with tumor size as a predictor.

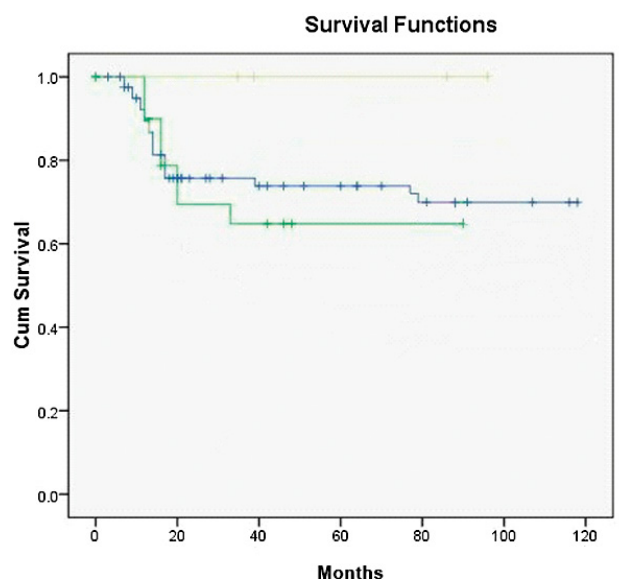

Fig. 4. Kaplan-Meier survival curve according to tumor grade.

G1-censored

G3-censored

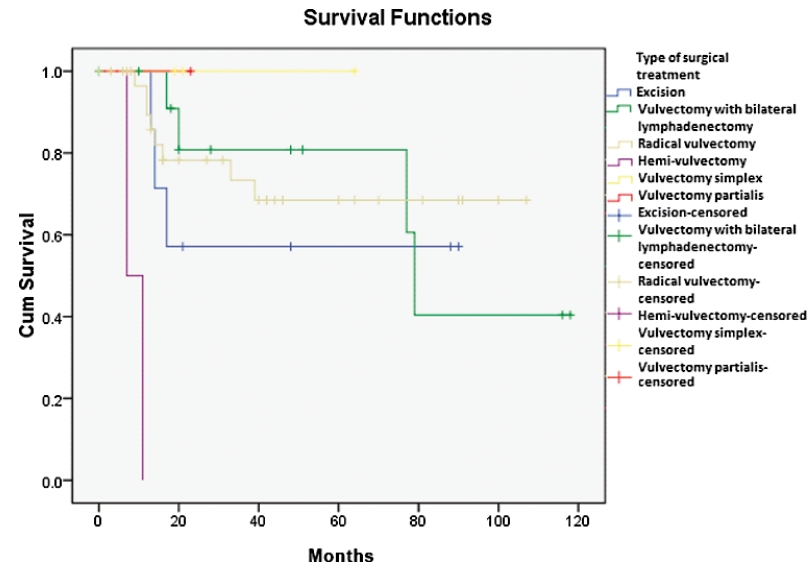

Fig. 5. Kaplan-Meier survival curve with mode of surgical treatment as a predictor.

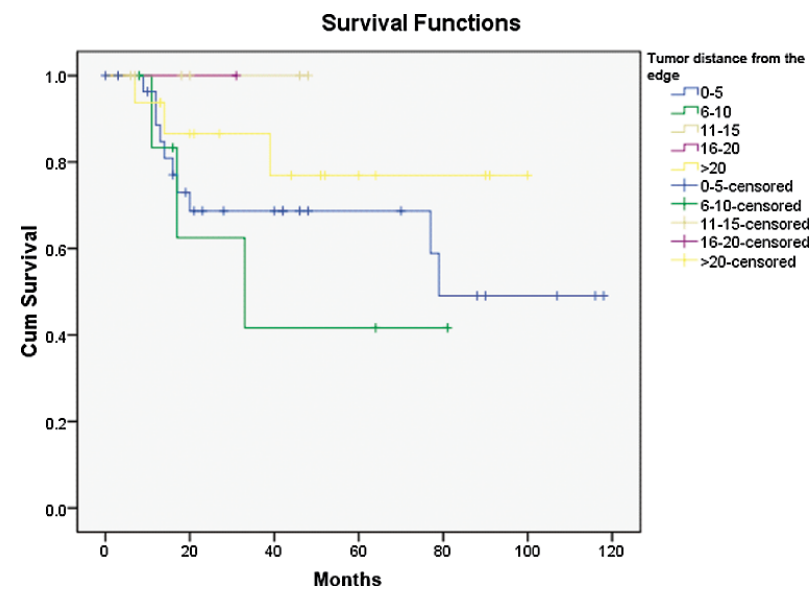

Fig. 6. Kaplan-Meier survival curve with tumor distance from the edge as a predictor.

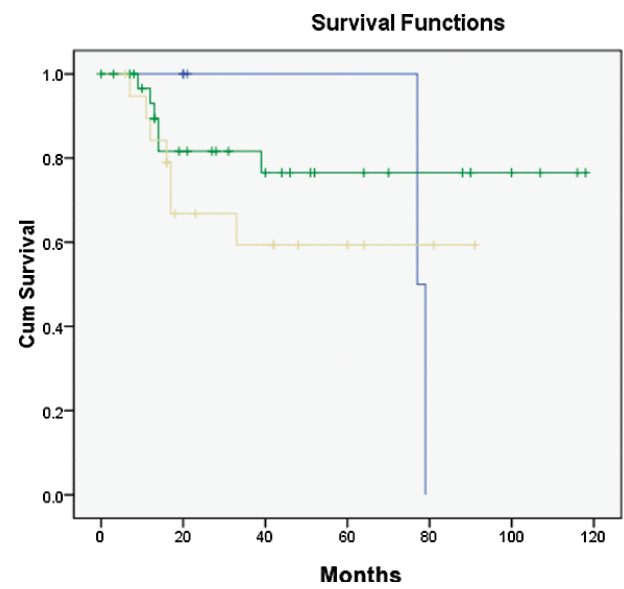

Depth of tumor invasion

$\neg<1$
$\neg 1-5$

$\rightarrow 5$

$+<1$-censored

$+<-$-censored
$+1-5-$ censored
$+5-$ censored

Fig. 7. Kaplan-Meier survival curve with depth of invasion as a predictor. 


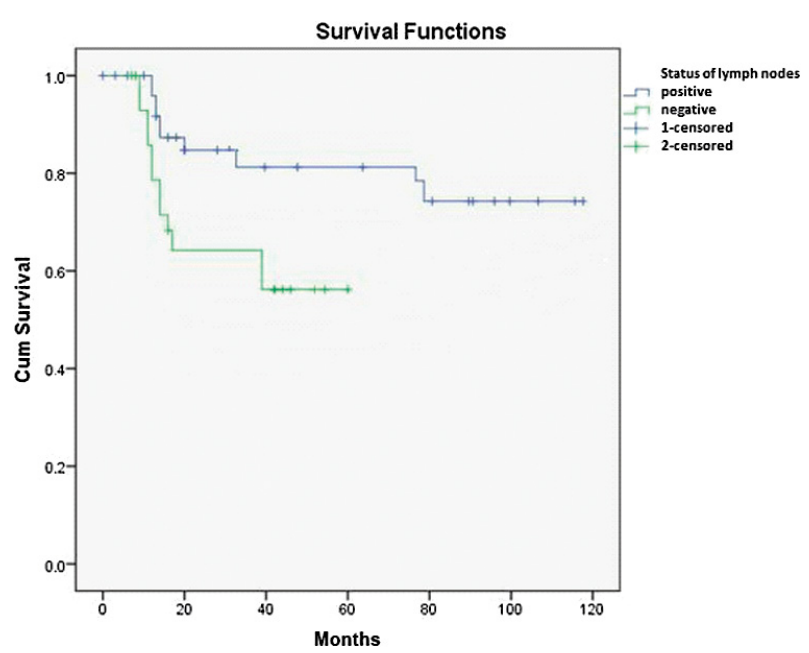

Fig. 8. Kaplan-Meier survival curve of positive lymph nodes.

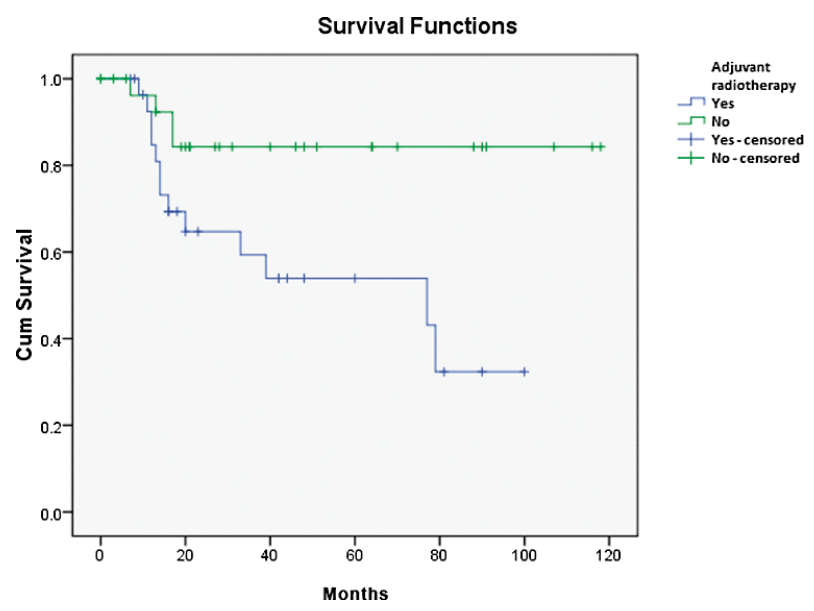

Fig. 9. Kaplan-Meier survival curve with adjuvant radiotherapy and chemotherapy as a predictor.

ure 2 shows Kaplan-Meier curve of patient survival according to FIGO stage. None of the FIGO IV patients survived for more than 14 months. In the FIGO II and III groups, the five-year survival rate was equally poor (about 45\%), whereas none of the patients with FIGO stage I died. There was a statistically significant difference in survival between FIGO I stage and all other FIGO stages $(p<0.001)$, but on multivariate analysis, clinical stage did not prove to be an independent prognostic factor. FIGO stage I has the best prognosis in five-year survival.

The largest number of study patients had tumor size of $1-2 \mathrm{~cm}$ (39\%), followed by patients with tumor size of 2-3 cm (20\%), 3-4 cm (15\%), 4-5 cm (5\%), while $10 \%$ of patients had tumor size $>5 \mathrm{~cm}$.
Figure 3 shows Kaplan-Meier survival curve with tumor size as a predictor. The best survival was recorded in patients with the smallest tumor size $1-2 \mathrm{~cm}$ $(80 \%)$, while those with tumor size $>6 \mathrm{~cm}$ had poor survival (about 20\%). Tumor size was not found to be a statistically significant factor $(\mathrm{p}=0.122)$. Multivariate analysis did not yield tumor size as an independent prognostic factor.

Figure 4 shows Kaplan-Meier curve of survival according to tumor grade. The graph shows that moderately differentiated tumors had poor prognosis and overall survival of up to 32 months, while five-year survival in well-differentiated tumors was about $50 \%$. Difference in survival due to histologic grade did not reach statistical significance on either univariate or multivariate analysis $(\mathrm{p}=0.320)$.

Radical vulvectomy was performed in more than half of the patients (56\%). Vulvectomy was performed with bilateral lymphadenectomy in $22 \%$ and by excision in $12 \%$ of cases. Other methods of surgical treatment were represented by less than $10 \%$.

Figure 5 shows Kaplan-Meier survival curve with type of surgical treatment as a predictor. Vulvectomy with bilateral lymphadenectomy proved to be the most effective method of surgical treatment, then radical vulvectomy and excision, and hemivulvectomy. The method of surgical treatment was not a statistically significant factor for prognosis $(\mathrm{p}=0.222)$.

In the majority of patients (49\%), tumor distance from the edge was 0 to $5 \mathrm{~mm}$, followed by patients with tumor distance greater than $20 \mathrm{~mm}$ (27\%). The KaplanMeier survival curve for tumor distance from the edge as a predictor showed the best survival for patients with greater tumor distance from the edge of the preparation. If the tumor was $20 \mathrm{~mm}$ or more far from the edge of the preparation, survival was about $70 \%$, whereas in those with the tumor $6 \mathrm{~mm}$ far from the edge survival was about $40 \%$. Tumor distance from the edge of the preparation was not a significant factor on either univariate or multivariate analysis ( $\mathrm{p}=0.122)$ (Fig. 6).

The majority (57\%) and only $9 \%$ of patients had the depth of invasion of 1-5 $\mathrm{mm}$ and $<1 \mathrm{~mm}$, respectively. The Kaplan-Meier survival curve with the depth of invasion as a predictor shows poor survival rates in those with greater depth of tumor invasion in the stro$\mathrm{ma}$. At the depth of invasion of $2 \mathrm{~mm}$ and $3 \mathrm{~mm}$, survival was about $70 \%$ and $50 \%$, respectively. The longest survival was recorded in patients with the depth of 
Table 2. Binary logistic regression analysis of histologic type, staging, type of treatment, size and local tumor progression

\begin{tabular}{|l|l|l|l|l|l|l|l|l|}
\hline Parameter & B & SE & Wald & df & Sig. & Exp (B) & \multicolumn{3}{|l|}{$95 \%$ CI for Exp (B) } \\
\cline { 5 - 9 } & & & & & Lower & Upper \\
\hline Histologic type (1) & 38.777 & 44683.695 & 0.000 & 1 & 0.999 & $6.931 \mathrm{E} 16$ & 0.000 &. \\
Histologic type (2) & 19.810 & 41760.448 & 0.000 & 1 & 1.000 & $4.011 \mathrm{E} 8$ & 0.000 &. \\
Histologic grade (1) & -0.283 & 1.125 & 0.063 & 1 & 0.801 & 0.753 & 0.083 & 6.837 \\
Histologic grade (2) & -38.940 & 17691.716 & 0.000 & 1 & 0.998 & 0.000 & 0.000 &. \\
Clinical stage (1) & 38.435 & 11334.026 & 0.000 & 1 & 0.997 & $4.922 \mathrm{E} 16$ & 0.000 &. \\
Clinical stage (2) & 39.230 & 11334.026 & 0.000 & 1 & 0.997 & $1.090 \mathrm{E} 17$ & 0.000 &. \\
Clinical stage (3) & 59.653 & 26786.984 & 0.000 & 1 & 0.998 & $8.068 \mathrm{E} 25$ & 0.000 &. \\
Surgical treatment (1) & -21.372 & 7765.255 & 0.000 & 1 & 0.998 & 0.000 & 0.000 &. \\
Surgical treatment (2) & -22.214 & 7765.255 & 0.000 & 1 & 0.998 & 0.000 & 0.000 &. \\
Surgical treatment (3) & -0.010 & 28905.871 & 0.000 & 1 & 1.000 & 0.990 & 0.000 &. \\
Surgical treatment (4) & -2.220 & 24586.884 & 0.000 & 1 & 1.000 & 0.109 & 0.000 &. \\
Surgical treatment (5) & -6.967 & 41032.131 & .000 & 1 & 1.000 & 0.001 & 0.000 &. \\
Tumor distance from surgical & -0.176 & 0.127 & 1.919 & 1 & 0.166 & 0.839 & 0.654 & 1.076 \\
edge of the preparation & 0.049 & 0.063 & 0.608 & 1 & 0.436 & 1.051 & 0.928 & 1.190 \\
Depth of invasion & 3.290 & 0.890 & 5.46 & 1 & 0.020 & 8.28 & 2.010 & 15.283 \\
Lymph node status & -3.330 & 1.353 & 6.056 & 1 & 0.014 & 27.941 & 1.970 & 396.357 \\
Adjuvant radiotherapy & -0.011 & 0.041 & 0.076 & 1 & 0.783 & 0.989 & 0.913 & 1.071 \\
and chemotherapy & Tumor size & &
\end{tabular}

Histologic type according to level of differentiation: well/poor; histologic grade: GI, GII, clinical stage according to FIGO; mode of surgical treatment: 1) excision; 2) vulvectomy with bilateral lymphadenectomy; 3) radical vulvectomy; 4) hemivulvectomy; 5) vulvectomy simplex

invasion of $<1 \mathrm{~mm}$; in this group, only one patient died during the seven-year follow-up. The depth of invasion did not prove to be a statistically significant prognostic factor on either univariate or multivariate analysis (p>0.236) (Fig. 7).

Out of a total of 59 subjects, lymphadenectomy was performed in 44 patients. Of these, lymph nodes were negative in $28(63.7 \%)$ and positive in $16(36.3 \%)$ patients. On average, 16 lymph nodes were removed per lymphadenectomy, with 2.5 positive lymph nodes. Overall survival was $75.0 \%$ in the group of patients with negative lymph nodes and $56.3 \%$ in the group of patients with positive lymph nodes. Difference in survival according to lymph node status was statistically significant $(\mathrm{p}=0.045)$. On multivariate analysis, lymph node status was shown to be an independent prognostic factor (Fig. 8). In the group with positive lymph node status there was a statistically significant increase in the number of deaths. Positive lymph node status was observed in $36.4 \%$ of cases, with $43.7 \%$ mortality rate.
Kaplan-Meier survival curve with adjuvant radiotherapy and chemotherapy as a predictor shows that patients who did not receive adjuvant irradiation and chemotherapy had better survival (about 90\%), while those having received adjuvant irradiation and chemotherapy had poor survival (about 30\%). Adjuvant irradiation and chemotherapy proved to be a statistically significant factor on univariate analysis $(\mathrm{p}=0.002)$ and an independent prognostic factor on multivariate analysis ( $p=0.014)$ (Fig. 9).

To assess the effect of independent factors on the likelihood that patients will die, binary logistic regression analysis was performed. The model contained 9 independent factors. The complete model of all nine factors was statistically significant $\left(\chi^{2}(\mathrm{~N}=59)=39.454\right.$; $\mathrm{p}<0.01)$, which indicates that the model successfully differentiated deaths. As shown in Table 2, two of the nine predictors were found to be equally significant (lymph node status and adjuvant therapy) for this model. The most important individual predictor was 
adjuvant therapy, i.e. the patients having received adjuvant therapy would have a 28 -fold greater probability to die. Lymph node status was another significant factor, i.e. the patients with positive lymph nodes would have an 8.3-fold greater chance of lethal outcome. Other factors, although important for the overall model, did not contribute to predicting death individually (Table 2).

\section{Discussion}

The survey involved 59 respondents. The highest incidence of vulvar cancer was recorded between 65 and 76 years (23\%), which is consistent with literature data. According to Cárcamo et al., the five-year overall survival rate for vulvar cancer was $41 \%$. In our research, the five-year overall survival was $72.9 \%$, illustrating how survival has increased compared to previous studies ${ }^{5}$.

According to Raspagliesi et al., age is a statistically significant prognostic factor ${ }^{3}$. The study by Sun et al. confirmed previous researches, and they also suggest univariate and multivariate prognostic significance of age $^{6}$. In our research, age did not prove to be a statistically significant factor $(\mathrm{p}=0.654)$.

The most commonly reported histologic type of tumor is squamous cell carcinoma (96\%) with survival of about $71.9 \%$. Univariate analysis showed that histologic type was not statistically significant in prognosis, and multivariate analysis showed that histologic type was not independently prognostically significant $(p=0.572)$. In a number of studies, histologic type was statistically significant for prognosis on univariate analysis ${ }^{2-6}$.

In our study, FIGO stage II was detected in 37\% of women with vulvar cancer. Overall survival was $100 \%$ in FIGO stage I 63.6\% in FIGO II, 60\% in FIGO III, and $0 \%$ in FIGO IV. In the study by Konidaris et al., survival was 93\% in FIGO stage I, 85\% in FIGO II, $50 \%$ in FIGO III, and $0 \%$ in FIGO IV7. In our research, FIGO stage proved to be a statistically significant factor $(\mathrm{p}=0.001)$. There was a significant difference in survival between FIGO stage I and all other FIGO stages, but clinical stage was not shown as an independent factor on multivariate analysis ${ }^{7}$. Coleman et al. showed that FIGO stage was a statistically significant factor on univariate analysis, and unlike our study, showed FIGO stage to be an independent prognostic factor on multivariate analysis ${ }^{8}$.
According to the study conducted by Paladini et al. ${ }^{9}$, tumor size was statistically significant in the prognosis, whereas our study showed that tumor size was not a prognostically significant factor. In our study, the largest number of women (39\%) had tumor size of 1-2 cm with $80 \%$ survival.

Our results showed well-differentiated tumors (G1) to be the most common histopathologic finding with $72.1 \%$ survival. Difference in survival according to histologic grade showed no statistical significance on either univariate or multivariate analysis $(\mathrm{p}=0.320)$. Some other studies report on histologic grade to be statistically significant in the prognosis of vulvar cancer on univariate analysis and an independent prognostic factor on multivariate analysis ${ }^{3}$.

Considering the type of surgical treatment as a prognostic factor, our data were not consistent with other studies, which report on the mode of surgical treatment to be a statistically significant factor in the prognosis of vulvar cancer ${ }^{7}$, whereas in our study univariate analysis suggested that the method of surgical treatment was not a statistically significant factor $(\mathrm{p}=0.222)$.

According to Woelber et al. ${ }^{10}$, tumor distance from surgical edge of the preparation has a statistically significant role in survival. In our study, the best survival was recorded in patients whose tumor was more distant from the edge of the preparation (about 70\%); however, tumor distance from the edge of the preparation did not prove to be statistically significant on either univariate or multivariate analysis $(\mathrm{p}=0.122)$

According to the study by Nicoletto et al. ${ }^{11}$, the depth of tumor invasion in stroma is a statistically significant factor in prognosis, and a similar study showed the depth of invasion to be an independent prognostic factor in diagnosis ${ }^{12}$. In our study, the depth of invasion did not prove to be a statistically significant factor $(\mathrm{p}=0.675)$ or an independent factor.

According to the research conducted by Chan et $a l^{12}$, lymph node status also has an independent prognostic significance. Recent researches confirm the previous ones, and they also speak of prognostic significance, seen as univariate and independent prognostic significance, seen as multivariate ${ }^{9,13,14}$. In our study, lymph node status was also shown to be a statistically significant and independent prognostic factor $(\mathrm{p}=0.045)$.

According to literature data, the more lymph nodes are affected, the worse survival is ${ }^{13-17}$. According to the 
study by Tan et al., adjuvant radiotherapy and chemotherapy proved to be a statistically significant factor ${ }^{18}$. Our study showed the same results. The patients that received adjuvant irradiation and chemotherapy had poorer survival than those that did not receive it. One of the reasons is that patients having received adjuvant radiotherapy and chemotherapy had been detected at a later stage of the disease, with greater tumor size and greater depth of tumor invasion in the stroma, with positive lymph nodes, so that all factors together contributed to poor survival.

\section{Conclusion}

Univariate analysis showed the lymph node status, adjuvant radiotherapy and chemotherapy, along with clinical staging of the disease to be statistically significant prognostic factors for survival of vulvar cancer patients. On multivariate analysis, the lymph node status, adjuvant radiotherapy and chemotherapy were positive independent prognostic factors for survival of vulvar cancer patients.

\section{References}

1. Salani R, Khanna N, Frimer M, Bristow RE, Chen LM. An update on post-treatment surveillance and diagnosis of recurrence in women with gynecologic malignancies: Society of Gynecologic Oncology (SGO) recommendations. Gynecol Oncol. 2017;146(1):3-10. doi: 10.1016/j.ygyno.2017.03.022

2. Rogers LJ, Howard B, Van Wijk L, Wei W, Dehaeck K, Soeters $\mathrm{R}$, Denny LA. Chemoradiation in advanced vulval carcinoma. Int J Gynecol Cancer. 2009;19:745-7. doi: 10.1111/IGC.0b 013e3181a13021

3. Raspagliesi F, Hanozet F, Dittoa A, Solima E, Zanaboni F, Vecchione F, Kusamura S. Clinical and pathological factors in squamous cell carcinoma of the vulva. Gynecol Oncol. 2006; 102(2):333-7. doi: 10.1016/j.ygyno.2005.12.027

4. Stehman FB. Invasive cancer of the vulva. In: DiSaia PJ, Creasman WT, editors. Clinical Gynecologic Oncology, $7^{\text {th }}$. ed. Philadelphia: Mosby, Elsevier; 2007.

5. Cárcamo M, Orellana JJ, Gayán P, Valenzuela MT. Survival of patients with vulvar cancer. Rev Med Chil. 2010;138(6):723-8. doi: $10.4067 /$ s0034-98872010000600009

6. Sun X, Zhang Y, Sun J, Feng S, Yan M, Cheng H. The comparative study of former and latest FIGO staging of vulvar cancer. Minerva Chir. 2012;67(2):187-95.

7. Konidaris S, Bakas P, Gregoriou O, Kalampokas Th, KondiPafiti A. Surgical management of invasive carcinoma of the vulva, a retrospective analysis and review. Eur J Gynaecol Oncol. 2011;32(5):505-8.
8. Coleman RL, Ali S, Levenback CF, Gold MA, Fowler JM, Judson PL, Bell MC, De Geest K, Spirtos NM, Potkul RK, Leitao MM Jr, Bakkum-Gamez JN, Rossi EC, Lentz SS, Burke JJ $2^{\text {nd }}$, Van Le L, Trimble CL. Is bilateral lymphadenectomy for midline squamous carcinoma of the vulva always necessary? An analysis. Gynecologic Oncology Group (GOG) 173. Gynecol Oncol. 2013;128(2):155-9. doi: 10.1016/j.ygyno.2012.11.034

9. Paladini D, Cross P, Lopes A, Monaghan JM. Prognostic significance of lymph node variables in squamous cell carcinoma of the vulva. Cancer. 1994;74(9):2491-6. doi: 10.1002/10970142(19941101)

10. Woelber L, Mahner S, Voelker K, Euenberg CZ, Gieseking F, Choschzick M, Jaenicke F, Schwarz J. Clinicopathological prognostic factors and patterns of recurrence in vulvar cancer. Anticancer Res. 2009;29(2):545-52.

11. Nicoletto MO, Parenti A, Del Bianco P, Lombardi G, Pedrini L, Pizzi S, Carli P, Della Palma M, Pastorelli D, Corti L, Becagli L. Vulvar cancer: prognostic factors. Anticancer Res. 2010; 30(6):2311-7.

12. Chan JK, Sugiyama V, Pham H, Gu M, Rutgers J, Osann K, Cheung MK, Berman ML, Disaia PJ. Margin distance and other clinico-pathologic prognostic factors in vulvar carcinoma: a multivariate analysis. Gynecol Oncol. 2007;104(3): 636-41. doi: 10.1016/j.ygyno.2006.10.004

13. Sznurkowski JJ, Milczek T, Emerich J. Prognostic factors and a value of 2009. FIGO staging system in vulvar cancer. Arch Gynecol Obstet. 2013;287(6):1211-8. doi: 10.1007/s00404-0122683-x

14. Faul CM, Mirmow D, Huang Q, Gerszten K, Day R, Jones MW. Adjuvant radiation for vulvar carcinoma: improved local control. Int J Radiat Oncol Biol Phys. 1997;38:381-9. doi: 10.1016/s0360-3016(97)82500-x

15. Rouzier R, Haddad B, Atallah D, Dubois P, Paniel BJ. Surgery for vulvar cancer. Clin Obstet Gynecol. 2005;48:869-78. doi: 10.1097/01.grf.0000179667.76068.7f

16. Viswanathan AN, Pinto AP, Schultz D, Berkowitz R, Crum $\mathrm{CP}$. Relationship of margin status and radiation dose to recurrence in post-operative vulvar carcinoma. Gynecol Oncol. 2007;104:636-41. doi: 10.1016/j.ygyno.2013.05.036

17. Koh WJ, Greer BE, Abu-Rustum N, Campos S, Cho K, Chon HS, Chu C, Cohn D, Crispens M, Dizon D, Dorigo O, Eifel P, Fisher C, Frederick P, Gaffney D, Han E, Higgins S, Huh W, Lurain JR, Mariani A, Mutch D, Nagel C, Nekhlyudov L, Nickles Fader A, et al. Vulvar Cancer, Version 1.2017, NCCN Clinical Practice Guidelines in Oncology. J Natl Compr Canc Netw. 2017;15:92-120. doi: 10.6004/jnccn.2017.0008

18. Tan J, Chetty N, Kondalsamy-Chennakesavan S, Crandon A, Garrett A, Land R, Nascimento M, Nicklin J, Perrin L, Obermair A. Validation of the FIGO 2009 staging system for carcinoma of the vulva. Int J Gynecol Cancer. 2012;22:498-502. doi: 10.1097/IGC.0b013e318241d994 
Sažetak

\section{PROGNOSTIČKI ČIMBENICI RAKA VULVE}

\section{Miljanović-Špika, M. Drežnjak Madunic, Z. Topolovec, D. Kujadin Kenjereš i D. Vidosavljević}

Cilj ove retrospektivne studije bio je istražiti utjecaj kliničkih, patoloških, citoloških i terapijskih prognostičkih čimbenika na ishod liječenja i preživljavanje bolesnica s karcinomom vulve te utvrditi prognostičko značenje svakog od pojedinačnih čimbenika kao i njihovo uzajamno značenje i utjecaj na sveukupno preživljavanje. Istraživanje je obuhvatilo bolesnice liječene od karcinoma vulve u razdoblju od 2000. do 2011. godine na Klinici za ginekologiju i porodništvo KBC-a Osijek. Retrospektivna analiza je obuhvaćala njihove povijesti bolesti zajedno s patološkim i citološkim nalazima te nalazima onkologa. Studija je obuhvatila 59 bolesnica u dobi od 45 do 88 godina. Dijagnoza se temeljila na patološkom i citološkom statusu i stadiju. Kao statistički značajni prognostički čimbenici preživljavanja bolesnica s karcinomom vulve u univarijatnoj analizi pokazali su se status limfnih čvorova, adjuvantna radioterapija, kemoterapija i klinički stadij bolesti. U multivarijatnoj analizi neovisnih prognostičkih čimbenika za preživljavanje bolesnica s karcinomom vulve, status limfnih čvorova, pomoćna terapija zračenjem i kemoterapija smatrani su pozitivnim prognostičkim čimbenicima.

Ključne riječi: Vulva; Rak; Preživljavanje; Kemoterapija; Stadij 